\title{
THE MEDIATING ROLE OF ETHICS IN THE RELATIONSHIP BETWEEN ATTITUDES AND CORRUPTION
}

\author{
Marwah Zuhaira \\ School of Management, Harbin Institute of Technology, Harbin, Heilongjiang, P.R.China \\ Ye-Zhuang Tian \\ School of Management, Harbin Institute of Technology, Harbin, Heilongjiang, P.R.China \\ Zaid Mahmood \\ School of Management, Harbin Institute of Technology, Harbin, Heilongjiang, P.R.China
}

\begin{abstract}
This research examines the roles of ethics in the relations between individual attitudes and corruption in Iraqi universities. Correlation analysis and linear regression are used to estimate the relations among individual attitudes, ethics, and corruption. Gleaned from 600 female and male workers, and analyzed with the SPSS software, the experimental data confirm that Individual attitude has negative associated with corruption. Also, ethics has negatively associated with corruption. Also, ethics mediates the relations between individual attitudes and corruption. But, this study has many limitations such as the generalizability of our outcome might be limited because we surveyed employees of a single sector in a single educational sector; this calls for future studies to verify the stability of our findings across sectors and firms. Second, supported data type may be accompanied by biasness in the results because it largely dependent on the individual sensations and feelings in an instant answer. This may confer a state of uncertainty and consistency in the answers.
\end{abstract}

Keywords: individual attitudes, ethics, corruption, Iraqi universities.

JEL code: M10

\section{Introduction}

Corruption is a serious problem causing damage and dilemma not only in politics and public administration but extends its impact to include business organizations. Because of this many researchers have been drawn from the various disciplines (economy, sociology, psychology, crime, political science and business ethics) to study this phenomenon and resolve the circumstances surrounding it (see Rabl and Kühlmann, 2008, Aidt, 2003). The concept of corruption also dates far back in history and might even be older than governments(see Klitgaard, 1988). There hasn't been enough research and theorizing explanations about the onset of corruption in Iraq. With time, there have been few definitions, explanations and taxonomies for public discourse about the problem. Given the tincture of corruption, the ready source rarely agrees with the definition- except probably, with consideration to bribery - and the translation of corruption tend to vary with social contexts and archetypical presumption. While researchers seek to supply a working, 'universal' definition of corruption, previous studies here suggest that we are further away to finding a universally definition that is understandable across and between 
cultures. Most of the studies deals with corruption in economic terms such that (see Paldam, 2001, Beets, 2007) neglected the ethical side which might be the best in the fight against corruption. Ethics is a division of philosophy that transacts with the rightness or wrongness of people's behavior such us corruption.

Corruption is expresses a fall from the highest to the lowest place(see Muhtaroglu and Quintern, 2014). Therefore, actions outside the law and its objectives informally change the moral course of events and attitudes to make things easier. Ortega et al. (2016) Sees this as a deviation from the correct moral behavior, referring to it as the opposite of a good reaction that is described as immoral. Here we see an agreement between Graaf and Aluko who focuses on overtaking a moral deviation from integrity (see Aluko, 2006). They added in the same direction with (Rabl and Kühlmann, 2008). Corruption as an immoral behavior includes a deviation from the rules, laws, and moral values, and this means that corrupt actors benefit from the power entrusted to them and their knowledge for personal interest. We see the need to focus on the ethical aspect when developing a definition of corruption with the support of Powpaka (2002) since he confirmed that many of the countries of the world are fighting bribery within the country and yet turn a blind eye to bribery to the outside world.

The core of corruption characteristics constitutes a moral sentence when there is an obligation to take a specific decision to stand out as this brings about a lot of ethical problems that excludes bribery. "Thailand-kind" gift giving process (hospitality, entertainment establishment party etc.) is very common and is not a part of corrupt practices. Giving bribes is a rational and systematic process that does not fall within the involuntary actions because as behavior is influenced by intention and behavioral control, more high-censorship can result in obstacles and barriers. The focus on government accountability, transparency and the separation of powers has led to the neglect of the moral side of the issue of corruption. And this neglect has affected the several failed attempts to resolve the issue. Adding insult to injury is the arrogance of the western world and the direction to adopt western rules and standards in the fight against corruption is globally binding (see Gebel, 2012). Finally, we can say that corruption is the slope at which an individual's moral and falling practices bring harm to others taking personal interests into consideration.

Leys (1964) and Leys (1965)argued that overly moralistic approaches to corruption-almost unique in social science-were hampering attempts at research, as well as the development of inadequate approaches to policy-making. Also, they noted that, 'Similar phenomena, such as suicide, crime, or religious fanaticism, have intrigued Psychologists greatly because ethics is influenced by the attitudes of the individual. However, the question of corruption in the contemporary world has so far been taken up almost solely by moralists. They used 'moralist' here to mean those whose starting point for corruption research was as a moral problem to be fought, rather than a social problem to be understood; what is interesting that was looking back at research in the years before 1965 when there was an explicit emphasis on morality in terms of corruption (see Marquette, 2012).

The behavior of the work environment depends on a sense of what is happening, and that depends on a sense of understanding of the attitudes of individuals. It is the intended attitudes of opinion and beliefs and feelings about the environment (Bauer et al., 1966). Attitudes are influenced by a person's values and interests as it has an impact on a person's response (see 
Badr et al., 2000). This means that there is a close link between the individual and the attitudes and behavior of the environment. For instance when working in an ethical work environment a person appears to be more committed and happier in the absence of bad behaviors( see Bauer et al., 1966). Attitudes involve people's cognitive, affective, and behavioral predispositions to respond to issues and an activity involving social standards for what is proper and virtuous. (see Preble and Reichel, 1988) found attitudes toward bribe effected ethical standard because the only moral of business is making money. Moore and Radloff (1996)added attitudes for students in South African was "business decisions involve a realistic economic attitude and not a moral philosophy."

The civilization brought about the concept of ethics. The ancient Egyptians considered this as the first concept of morality. This concept is as well known in different cultures. For instance, the Chinese refers to ethics as the concept of virtue and they associate it to the importance of the individual and the group at large. Greeks agree that morality is planned and has a substantial share in the monotheistic religions which includes Judaism, Christianity and Islam and it forms the basis of which people are raised and kept from falling into the human injustice. It is the mental judgment on what is acceptable or unacceptable morally (see Al-Ghamdi, 2001) . A set of rules governing the people's livelihood and social lives, and to provide guidelines on how to behave in society and assess others (see Rock, 2013). Ethics can refer to a set of moral standards in government, organizations and societies in which they operate to guide decisions, choices and actions (see Gebel, 2012). We believe that ethics is the evaluation of principles and standards of behavior control.

This study focused on bridging the gap and expand the study of the relationship between individual attitudes and corruption by ethical among employees in Iraqi universities. We want to find out whether the changes in individual attitudes can make employees more respectful of the ethical laws. Based on the Marquette (2012) opinion, which is considered to be starting in the fight against corruption, the point must be based upon moral values, which are evidence in making decisions for individuals. Because of giving a bribe is a rational process and systematic does not fall within the conduct involuntary, making it influenced by intention and behavioral control to increased obstacles and obstructions for corruption participants (see Powpaka, 2002). Therefore, the hypotheses proposed Ethics mediates the negative relationship between attitude toward corruption and corruption level. The paper includes four parts, the second part deals with the methodology; third part presents data analysis, finally Discussion and Conclusion.

\section{Methodology}

\subsection{Participants}

Participants included 804 employees at Iraqi University. Out of this population, were (644) responses from the participants and (44) questionnaires were neglected due to lack of right or other reasons. Finally 600 (75\%) activily participants were involved in the research. The subscriber characteristics included 391 males equivalent to 65\% and 209 females, an equivalent of $35 \%$. All the participants were adults in different managerial positions at the universities.

\subsection{Instrumentation:}

Corruption: The four items scale development by Stepurko et al. (2013)to measure corruption. Responses have ranging from 1, “always”, to 5, “never.” For example, "Do your prompt officials 
a gift or cash payment to meet with you to upgrade or change your career?” The reliability of the scale is 0.895 .

Attitudes toward corruption toward corruption: The four items scale development by Stepurko et al. (2013) to measure attitudes toward corruption. Responses have ranging from 1, "strongly agree”, to 5, "strongly disagree.” For example, "Have you considered a gift to you something like a bribe?” The reliability of the scale is 0.94 .

Ethics: The eight items scale development by Samanta (2011) to measure ethics. Responses have ranging from 1, "strongly agree”, to 5, "strongly disagree.” For example,"I must edit a profile of my goals in any way. "The reliability of the scale is 0.87 .

2.3 Data analysis techniques: we conducted multiple regressions analyses estimating the linear hypotheses for the mediate effects of ethics between individual attitudes and corruption in SPSS 20.

\section{Data analysis}

\subsection{Descriptive statistics}

Table 1. We can see Mean, standard deviation and bivariate correlation. Individual attitudes negatively associated with ethics and corruption $\left(\mathrm{r}=-0.11^{* *}\right.$ and $\left.-0.60 * *\right)$ and $(\mathrm{p}<0.01)$, and ethics also negatively associated with corruption $(r=-0.61, \mathrm{p}<0.01)$.

Table 1. Means, standard deviations, and correlations for all variables.

\begin{tabular}{lllllll}
\hline Variable & Mean & SD & 1 & 2 & 3 & 4 \\
\hline 1. Age & 0.60 & 0.48 & & & & \\
2. Gender & 2.57 & 1.11 & -0.07 & & & \\
6. individual attitudes & 3.65 & 0.85 & 0.003 & -0.042 & & \\
4. Ethics & 3.66 & 0.86 & -0.01 & -0.047 & $-0.11^{* *}$ & \\
5. Corruption & 1.96 & 1.09 & 0.06 & -0.006 & $-0.60^{* *}$ & $-0.61^{* *}$ \\
\hline
\end{tabular}

Note: $\mathrm{N}=600 .{ }^{* *} \mathrm{p}<0.01$.

\subsection{Testing of Hypotheses}

The purpose of this section is to investigate the effect of attitudes toward corruption on corruption levels in organizations by ethics. Table 2. Shows the results of regression analysis conducted to examine the mediation effect of ethics on the relationship between attitudes and corruption. Correlation results indicate that with exception of age and gender were insignificant predictor of ethics as a mediator variable (see model 1 ). Model 2 reports that the attitudes explain 0.81 percent of the variation of the ethics (adjusted $R^{2}=77 \%$ ), when $F$ - value greater than scheduled values. The coefficient is positive and significant (81\%), and this is consistent with our hypotheses. The attitudes have been positively associate with ethics.

The attitudes increases by $81 \%$ when ethic's increases by $1 \%$. The third model shows that ethics and attitudes explain 36 percent of variation of the corruption (adjusted $\mathrm{R}^{2} 40 \%$ ). Coefficient ($0.36)$ is less than in the second model $(-0.72)$ that indicates statistically ethics is a mediator variable, which is not consistent with our hypotheses. On the other hand, the corruption lowering $40 \%$ when ethics increase $1 \%$, and corruption decrease $45 \%$ when attitudes increase $1 \%$. The 
effects of are negative and significant (-0.40) and -0.45) respectively. From above, the attitudes have affected corruption by $-0.72 \%$, which considers a high role for anti-corruption by adoption social tools. Until recently, few articles have been managed to investigate why the corruption phenomenon is not finished and which economies have been high affected the corruption level.

Table 2. The mediating role of ethics between individual attitudes and corruption levels for employees

\begin{tabular}{|c|c|c|c|c|c|c|}
\hline \multirow{2}{*}{ Variable } & \multicolumn{2}{|l|}{ Corruption } & \multicolumn{2}{|c|}{ Ethics } & \multicolumn{2}{|l|}{ Corruption } \\
\hline & Model 1 & SE. & Model 2 & SE. & Model 3 & SE. \\
\hline control variable & & & & & & \\
\hline Age & 0.049 & 0.03 & 0.009 & 0.02 & $0.052^{*}$ & 0.03 \\
\hline $\begin{array}{l}\text { Gender } \\
\text { indenendent variable }\end{array}$ & -0.027 & 0.07 & -0.04 & 0.03 & -0.047 & 0.07 \\
\hline Individual attitudes & $-0.72 * * *$ & 0.04 & $0.81^{* * *}$ & 0.02 & $-0.36 * * *$ & 0.08 \\
\hline $\begin{array}{l}\text { Mediating variable } \\
\text { Ethics }\end{array}$ & & & & & $-0.45 * * *$ & 0.08 \\
\hline $\begin{array}{l}\text { Adjusted R² } \\
\text { F-value }\end{array}$ & $\begin{array}{c}0.37 \\
118.11^{* * *}\end{array}$ & & $\begin{array}{c}0.77 \\
653.48^{* * *}\end{array}$ & & $\begin{array}{c}0.40 \\
99.70^{* * *}\end{array}$ & \\
\hline
\end{tabular}

Note: $\mathrm{N}=600,{ }^{*} \mathrm{p}<0.1,{ }^{* *} \mathrm{p}<0.05,{ }^{* * *} \mathrm{p}<0.01$

\section{Discussion and Conclusion}

In this study, we explored the relationship between Individual attitudes, ethics and corruption at universities in Iraq. The results found that Individual attitudes have negatively associated with corruption. Also, ethics has negatively associated with corruption, and this is in line with Bloom and Arikan (2012) they confirmed the higher level of ethical behavior of the individual stayed away from corruption. Powpaka (2002) Which found that corruption is unethical behavior leads to the destruction of trust; high morals' owners sometimes engaged in corrupt actions as a result of a boost by the authority. When we want to reduce corruption, we must monitor ethics (see Juntunen et al., 2008). Janoff-Bulman et al. (2009) and Janoff-Bulman and Sheikh (2006) added that increased levels of ethics reduce immorality and bad actions.

To test the hypotheses of mediation should examine three conditions that establish the role of mediation effect. Firstly, the independent variable significantly has affected mediator variable that account the variations in the mediator. Secondly, the independent variable must be shown to affect the dependent variable. Thirdly, the mediator variable significantly has affected dependent variable. If these conditions hold in predicted direction then, the effect of independent variable must be less in the third examining than in the second examining. Perfect mediation hold if the independent variable has no effect when the mediator is controlled (see Baron and Kenny, 1986, Hayes, 2013), On the basis of that we found ethics partial mediating between individual attitudes and corruption. We see that corrupt behaviors of employees would bring about lesser job satisfaction and is likely to indicate less right attitudes and ethics to remain on the job, or students' corrupt behavior will reduce their efficiency in the future performance. Finally, 
recommendations for effective and successful organizational management were added to existing literature.

This study has diverse limitations that further research should endeavor to conquer. First, the generalizability of our outcome might be limited because we surveyed employees of a single sector in a single educational sector; this calls for future studies to verify the stability of our findings across sectors and firms. Second, supported data type may be accompanied by biasness in the results because it largely dependent on the individual sensations and feelings in an instant answer. This may confer a state of uncertainty and consistency in the answers. To study the effects of confidence and life satisfaction is one of the important steps in the future. It is possible that there will be the effect of the levels of confidence and satisfaction on corruption. Also, the current study does not provide any clarification on the feeling of happiness, and the effect of an individual's sense of injustice in the field of corruption. 


\section{References}

Aidt, T. S. 2003. Economic analysis of corruption: a survey. The Economic Journal, 113, F632F652.

Al-Ghamdi, M. 2001. The anti-inflammatory, analgesic and antipyretic activity of Nigella sativa. Journal of ethnopharmacology, 76, 45-48.

Aluko, J. 2006. Corruption in the local government system in Nigeria, Ibadan. Book Builders Editions.

Badr, A., sch, R., Rabey, H. E., EffgeN, S., Ibrahim, H., Pozzi, C., Rohde, W. \& Salamini, F. 2000. On the origin and domestication history of barley (Hordeum vulgare). Molecular Biology and Evolution, 17, 499-510.

Baron, R. M. \& Kenny, D. A. 1986. The moderator-mediator variable distinction in social psychological research: Conceptual, strategic, and statistical considerations. Journal of personality and social psychology, 51, 1173.

Bauer, A., Kirby, W., Sherris, J. C. \& Turck, M. 1966. Antibiotic susceptibility testing by a standardized single disk method. American journal of clinical pathology, 45, 493.

Beets, S. 2007. Global corruption and religion: an empirical examination. Journal of Global Ethics, 3, 69-85.

Bloom, P. B.-N. \& Arikan, G. 2012. A two-edged sword: The differential effect of religious belief and religious social context on attitudes towards democracy. Political Behavior, 34, 249276.

Gebel, A. C. 2012. Human nature and morality in the anti - corruption discourse of transparency international. Public Administration and Development, 32, 109-128.

Hayes, A. F. 2013. Introduction to mediation, moderation, and conditional process analysis: A regression-based approach, Guilford Press.

Janoff-Bulman, R. \& Sheikh, S. 2006. From national trauma to moralizing nation. Basic and Applied Social Psychology, 28, 325-332.

Janoff-Bulman, R., Sheikh, S. \& Hepp, S. 2009. Proscriptive versus prescriptive morality: two faces of moral regulation. Journal of personality and social psychology, 96, 521.

Juntunen, A., Käyhkö, E. \& Rotterdam, H. Police corruption, ethics and values of police and respondents A study based on a citizen survey in Finland. Ethics and Integrity of Governance Conference organized by the European Group of Public Administration in Rotterdam, September 3À6, 2008.

Klitgaard, R. 1988. Controlling corruption, Univ of California Press. 
Leys, C. 1964. The development of a University College of Mauritius, Mauritius Legislative Assembly.

Leys, C. 1965. What is the Problem about Corruption? The Journal of Modern African Studies, 3, 215-230.

Marquette, H. 2012. 'Finding God'or 'Moral Disengagement'in the Fight against Corruption in Developing Countries? Evidence from India and Nigeria. Public Administration and Development, 32, 11-26.

Moore, R. S. \& Radloff, S. E. 1996. Attitudes towards business ethics held by South African students. Journal of Business Ethics, 15, 863-869.

Muhtaroglu, N. \& Quintern, D. 2014. Islamic Philosophy and Occidental Phenomenology in Dialogue, Springer Netherlands.

Ortega, B., Casquero, A. \& Sanjuán, J. 2016. Corruption and Convergence in Human Development: Evidence from 69 Countries During 1990-2012. Social Indicators Research, 127, 691-719.

Paldam, M. 2001. Corruption and religion adding to the economic model. Kyklos, 54, 383-413.

Powpaka, S. 2002. Factors affecting managers' decision to bribe: An empirical investigation. Journal of Business Ethics, 40, 227-246.

Preble, J. F. \& Reichel, A. 1988. Attitudes towards business ethics of future managers in the US and Israel. Journal of Business Ethics, 941-949.

Rabl, T. \& Kühlmann, T. M. 2008. Understanding corruption in organizations-development and empirical assessment of an action model. Journal of business ethics, 82, 477-495.

Rock, M. S. 2013. New insights into corruption: Paradoxical effects of approach-orientation for powerholders, University of Massachusetts Amherst.

Samanta, S. K. 2011. Corruption, Religion and Economic Performance in OPEC Countries: An Analysis. International Journal of Economics, Management and Accounting, 19, 187.

Stepurko, T., Pavlova, M., Gryga, I. \& Groot, W. 2013. Informal payments for health care services-Corruption or gratitude? A study on public attitudes, perceptions and opinions in six Central and Eastern European countries. Communist and Post-Communist Studies, 46, 419-431. 